\title{
IMPLEMENTATION OF CHARACTER EDUCATION THROUGH CULTURE 5S (SENYUM, SAPA, SALAM, SOPAN DAN SANTUN) AT STATE JUNIOR HIGH SCHOOL 2 NGAWI (SMPN 2 NGAWI) EAST JAVA INDONESIA
}

\author{
Sri Wening Rahayu; Bambang Budi Wiyono; \\ I Nyoman Sudana Degeng; Ibrahim Bafadal \\ Universitas Negeri Malang \\ Email: sriweningr@yahoo.co.id
}

\begin{abstract}
This study aims to describe and find the implementation of character education through the $5 S$ culture at SMPN 2 Ngawi. Data collection techniques in this study using in-depth interviews, participatory observation and documentation. The results show that the implementation of character education through the application of $5 \mathrm{~S}$ culture in schools has proven effective, which can result in the cultivation of livable values of life, which can be a provision of community life. If the application of the $5 S$ culture is consistent, it can automatically improve school performance but also the school into a character education center followed by other schools.
\end{abstract}

Keywords: Character Education, Culture 5, SMPN 2 Ngawi

\section{INTRODUCTION}

The word "character" comes from the English "Character" of the Greek "Character", which used to mean the sign of a coin, but then is generally interpreted as a distinctive mark that distinguishes a set of qualities that distinguish one another (Homiak, 2007). Characteristic education of psychological and philosophical perspective states that a virtue can be taught and studied with the right education. Character education will be able to reconstruct students' ethical and social awareness abilities optimally in schools (Berkowitz, 2009). CEP (2010) Character education comprehensively can be done through the implementation of positive moral culture in the school environment and supported by the planting of values in learning in the classroom. Koesoema (2010: 123) argues "the character is the dynamic condition of the anthropological structure of the individual, who does not want to stop only on his natural determination, but also an attempt to become more integral to overcome determination in himself for the process of perfecting himself continuously" One form of character education Which is applied in SMPN 2 Ngawi is a culture of 5S (Senyum, Sapa, Salam, Sopan dan Santun). With the $5 \mathrm{~S}$ culture expected students to be a strong person, both in the realm of cognitive (knowledge), psychomotor domain (personality) Behavior), has a virtuous and polite attitude towards others. In addition, it will also benefit ourselves, the nation, and the country in welcoming the gold generation in the future (Ferryka, 2016). Lickona (2012) that the formation of good character needs to emphasize on the continuous guidance of behavior starting from the process of moral knowing, moral feeling, and moral action of character education.

According to Akhmad Sudrajat (2010), the benefits of developing a school culture include, as follows: (1) ensuring better quality of work; (2) open all communication networks of all kinds and levels of both vertical and horizontal communications; (3) more open and transparent; (4) creating a high sense of belonging and belonging; (4) promote solidarity and kinship; (5) if it finds an error will be fixed immediately; And (6) can adapt well to the development of Science and Technology. In addition to some of the above benefits, other benefits for individuals (personal) and groups are: (1) increasing job satisfaction; (2) more intimate relationships; (3) discipline increases; (4) functional oversight may be lighter; (5) the desire to always be proactive; 
(6) learning and achievement continue as well; And (7) always want to give the best for school, family, others and yourself.

Maisyaroh (2016) School needs to build and develop conducive culture and climate and to reduce and even eliminate negative culture and climate. The steps taken to build a conducive culture and climate are analyzing the external and internal conditions of the school, formulating strategies, implementing strategies, As well as monitor and evaluate school culture and climate.

Character education in psychological and physiological perspective is stated that virtue can be taught and learned through proper education (Cooley, 2008). Kemendiknas (2011: 7) states the three functions of character education, namely: (1) building a multicultural life of multiculturalism, (2) building intelligent civilization, noble culture, and able to contribute to the development of human life; Develop the basic potential to be good-hearted, good-minded, and well behaved and exemplary, and (3) build a peaceful, creative, independent, and able to coexist with other nations in a harmony. Culture $5 \mathrm{~S}$ which stands for Smile, Sapa, Salam, Polite and Santun is an eastern culture that is taught in the way of the descendants, with the intention to pay homage to the elderly. But in reality at this time, we suggest there is a decline in moral values in the generation of the nation Caused by modernization, it must be handled immediately through education in schools to cultivate the character and value of Indonesian character (Pratiwi, 2012).

Character education is needed to help students develop good character, caring, action based on ethical values such as respect, responsibility, honesty, justice and compassion (Pattern, 2011). As one way to educate the character of students is through 5S. SMPN 2 Ngawi is one of the leading schools of society, for several reasons, among others: 1) Has been an international school, 2) Adiwiyata Admiral, 3), Applying Curriculum 13, 4) has many academic and nonacademic achievements, 5). Strategic location, 6) Available facilities and adequate infrastructure, 7), conducive learning climate and 8). Applying various school cultures, one of them is $5 \mathrm{~S}$ culture. Culture $5 \mathrm{~S}$, in SMPN 2 Ngawi applied with the aim that students have good "tata krama" and have a "Nguwongke" attitude, meaning to respect and respect the parents, teachers, and other friends at school and outside of school. Even the $5 \mathrm{~S}$ culture is actually also the implementation of the Ngawi district motto with "Ngawi Ramah". Of the results, The interview is "friendly" here means is friendly with the environment, does not distinguish from religion, and background, so that the outsider is expected by the hospitality of wong Ngawi not hesitate to come to Ngawi. This is in accordance with the opinion of Agboola (2012) character education is a discipline developed with a conscious effort to maximize the ethical behavior of students whose outcomes can prepare the future leaders of the nation.

\section{METHOD}

This research use the qualitative approach. Data collection techniques used in-depth interview techniques, participatory observation, and documentation. His research design uses case studies. Ulfatin (2015) case studies can be interpreted as a direct method of inquiry with a natural setting and be focusing on an event intensively and in detail. Interview technique using semistructured interview technique, the informants are 1 principal, 4 vice principals, 6 teachers, 5 students, 2 staff of education personnel and 1 school committee. Research subjects used snowballing. Interviews regarding: 5S Cultural Meaning, 5S Cultural Objectives, 5S Cultural Implementation, Characteristic / Values of 5S Culture, and the role of teachers, schools, and parents in the $5 \mathrm{~S}$ culture. Observation techniques with regard to 4 self-development activities are routine activities, spontaneous activities, exemplary and conditioning. Documentation techniques obtained from a photocopy of the vision of the school mission, and culture $5 \mathrm{~S}$ either through writing or banner and photos of $5 \mathrm{~S}$ activities. Data analysis techniques using techniques from Miles and Huberman cited by Sugiyono (2010), with the steps: data reduction, data presentation, and withdrawal of conclusions/verification. Techniques The validity of the data using triangulation of sources and techniques.Triangulasi source by checking from various sources, while triangulation techniques by checking through the results of interviewing techniques, observation, and documentation. Member checks, extension of observation, increasing perseverance, discus- 
sion with colleagues and reference adequacy ( Creswell, 2009).

\section{RESULTS AND DISCUSSION}

First, Culture 5S, Culture 5S is an abbreviation of Smile, Sapa, Salam, Sopan dan Santun, is a culture of salute to all citizens of the school, every day by shaking hands, either while inside or outside the school. Smiling means giving a smile to every citizen of the school and the guests who come to school when meeting, Sapa means to say a greeting, like hi, how are you? Hail is to say a greeting like assalamualaikum, shalom, horas, etc. Sopan and Santun have respect, re- spect the elder, by behaving in accordance with the applicable ethics. Ujiningsih (2010: 3 ) argues that courtesy is a Javanese term that can be interpreted as a behavior of someone who upholds the value of respect, respect, not arrogant and noble. The embodiment or manifestation of this courtesy attitude is a behavior that respects others through communication using language that does not undermine or degrade others. In Javanese culture a polite attitude of one is characterized by respectful behavior to an older person, using polite language, not possessing an arrogant nature.

The application of culture 5S in State Junior High School 2 Ngawi will describe in table 1. Documentation results can be traced through

Table 1: Activities that include self-development

\begin{tabular}{|c|c|c|}
\hline No & Aspects of activities & Form of activity \\
\hline \multirow[t]{4}{*}{1} & Routine activities & $\begin{array}{l}\text { 1. Every day there are some teachers who lined the gate of } \\
\text { the school to welcome the presence of students, Students } \\
\text { shake hands and kissed the hands of their teacher's. }\end{array}$ \\
\hline & & 2. The entire school community shook hands at each other. \\
\hline & & $\begin{array}{l}\text { 3. Students at the time before the start of the study, and } \\
\text { after finished learning shake hands with the father of the } \\
\text { mother who teaches in the class. }\end{array}$ \\
\hline & & $\begin{array}{l}\text { 4. Every student goes to school shake hands with their } \\
\text { respective parents. }\end{array}$ \\
\hline \multirow[t]{3}{*}{2} & Spontaneous Activities & $\begin{array}{l}\text { 1. Meeting school residents outside the school should apply } \\
\text { the } 5 \mathrm{~S} \text { culture. }\end{array}$ \\
\hline & & 2. If there is a school guest, it should give a smile. \\
\hline & & 3. Ask about the news and conditions of today. \\
\hline \multirow[t]{4}{*}{3} & Exemplary & $\begin{array}{l}\text { 1. Every morning the principal always comes early to wel- } \\
\text { come the children. }\end{array}$ \\
\hline & & 2. The mother of the teachers also applies the $5 \mathrm{~S}$ culture. \\
\hline & & 3. Teachers and education personnel also greet one another. \\
\hline & & $\begin{array}{l}\text { 4. Headmasters become role models for school residents, } \\
\text { teachers become role models for students, older siblings } \\
\text { become young and for younger siblings }\end{array}$ \\
\hline \multirow[t]{3}{*}{4} & Conditioning & 1. Installed slogans about $5 \mathrm{~S}$ \\
\hline & & 2. Written in a school program document. \\
\hline & & 3. Implemented daily. \\
\hline
\end{tabular}


school program documents, school vision visions, photographs, and videos as evidence of the $5 \mathrm{~S}$ cultural implementation at SMPN 2 Ngawi.

Second, the purpose of the $5 \mathrm{~S}$ culture is to have good character, to have a good identity, to provide societal association, to succeed Ngawi city program with the motto "Ngawi Ramah" and achieve the vision of school mission. As outlined by the Directorate of Education Personnel of the Directorate General for the Improvement of Quality of Educators and Education Personnel of the Ministry of National Education in 2007 on Culture and Climate Development Learning in Schools, one of the efforts to develop a school culture should refer to the vision, mission and objectives of the school. The function of school vision, mission, and objectives is to direct the development of school culture. The vision of quality excellence, for example, should be accompanied by concrete programs on the creation of school culture (Sudrajat, 2011).

Third, the implementation of $5 \mathrm{~S}$ culture at SMPN 2 Ngawi. The result of the interview, stated that the $5 \mathrm{~S}$ culture has been applied in SMPN 2 Ngawi as a lifestyle that reflects the characteristics of students of SMPN 2 Ngawi, because it is a routine to be carried away at home, when leaving school to shake hands, ask for blessings to parents, Meet with all their school residents applying the $5 \mathrm{~S}$ culture. The results of the observations that researchers do base on findings from Gunawan (2012) suggests the implementation strategy of $5 \mathrm{~S}$ culture, can be done through self-development studies, in 4 activities, among others: 1) routine activities are activities that students do regularly and continuously.2) Spontaneous activity is an activity that is done by unplanned on the spot.3. Exemplary is the behavior and attitude of teachers and education personnel in providing an example through good action and 4) Conditioning is the creation of conditions to support the implementation of character education. It is stated that the $5 \mathrm{~S}$ culture has been implemented consistently, can be seen from the following table 1 .

Fourth, the characteristics/values of the 5S cultural implementation in SMPN 2 Ngawi, among others: have a friendly attitude, caring for others, tolerance, have etiquette, have a respectful attitude and respect the elderly, have a noble sense, and uphold Cultural ethics. And have the provision to live in a multicultural society. Character values generated from the $5 \mathrm{~S}$ culture are very important to counteract the negative effects of globalization. One of the effects of globalization is the rapid change of socio-cultural values that can lead to mental disorders and the welfare of society, so multisectoral, holistic, and responsible management is needed to create a culture that can counteract the stressors created by the global world (Sharma, 2016). Example of research results as follows: The higher the self-control the lower the tendency of juvenile delinquency behavior, on the contrary, the lower the level of self-control in SMK X, the higher the tendency of juvenile delinquency (Aroma, 2012).

Fifth, the role of teachers, parents, and schools in the implementation of $5 \mathrm{~S}$ culture at SMPN 2 Ngawi. The role of teachers in this case teachers should continue to give direction, admonition to students if they forget to implement the $5 \mathrm{~S}$ culture in school, Parents role, should always remind the importance of applying the $5 \mathrm{~S}$ habituation at home and when meeting with anyone should give smile, greetings and greetings and behave Polite and courteous, Gunarso (2010) Parents are not the only determinants for the moral development of children, but parents have the most important role to guide the moral development of children. While the role of school, the school should be a container of character building by applying the $5 \mathrm{~S}$ culture.

There is a process to built character education at SMPN 2 Ngawi. This process will describe in Figure 1.

Sixth, the process of character education through the $5 \mathrm{~S}$ culture can be seen in the scheme 1. The first process is analize the decline of morality for next generation. After that the government will design character education. Schools have purpose to develop potency of citizen. SMPN 2 Ngawi also implementation of character education through $5 \mathrm{~S}$ culture until visible in scholl vision and mission.

\section{CONCLUSION}

First, Culture 5S (Smiles, Sapa, Greetings, Polite and courteous) is one of the implementation of character education held in SMPN 2 Ngawi. This is based on the reason that character education should be implemented because of it Shifts in 


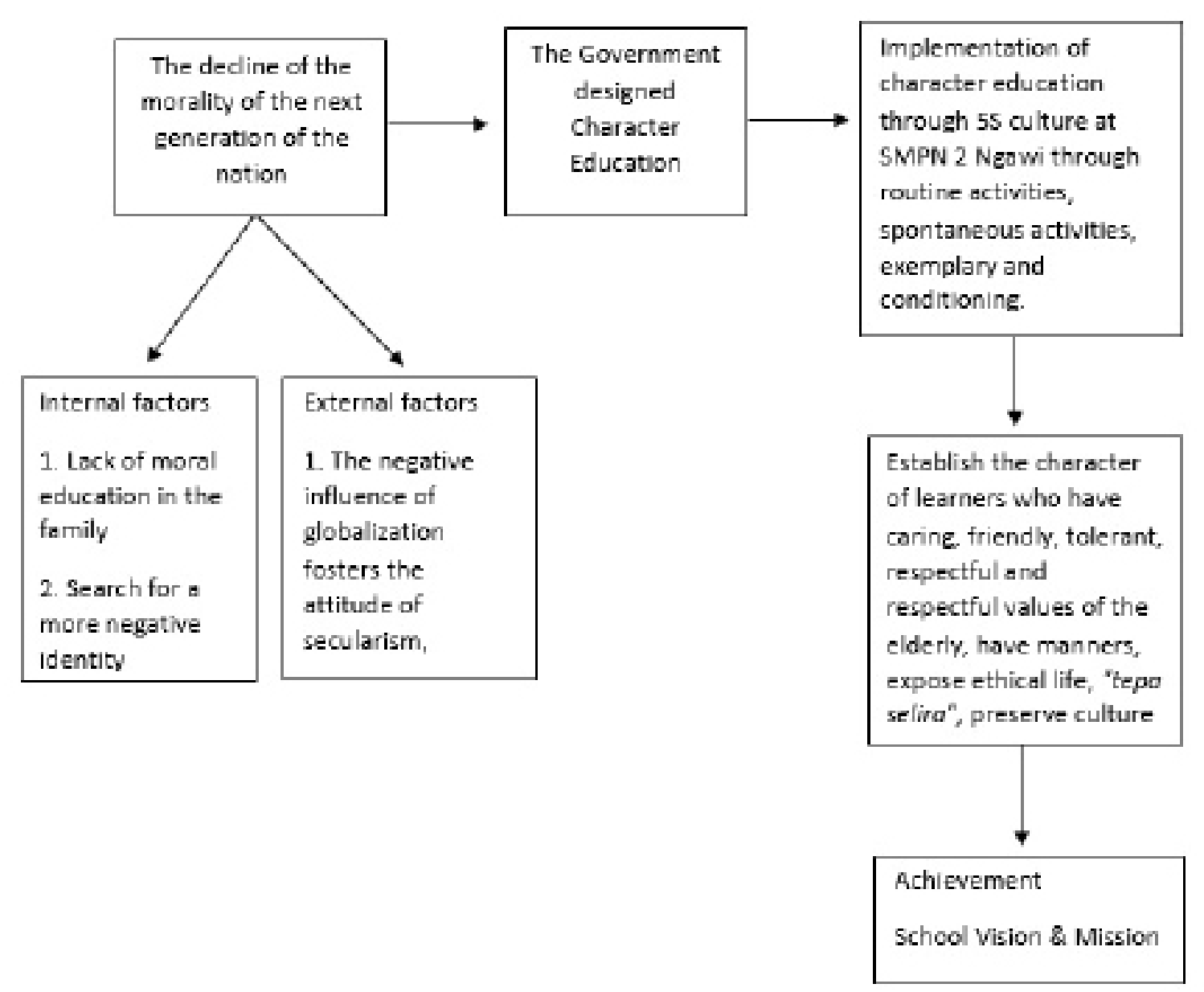

Figure 1 Process of Charakter 5S SMPN 2 Ngawi

the values of nation and state life that result in the nation's cultural values, and undermine the morality of the younger generation.

Second, the goal of the implementation of character education through the $5 \mathrm{~S}$ culture is that learners have a commendable character, have provision for social life in the community, realizing the vision of the school mission.

Third, the implementation of character education through the $5 \mathrm{~S}$ culture has been applied in SMPN 2 Ngawi through routine activities, spontaneous activities, exemplary and conditioning.

Fourth, the implementation of character education through the $5 \mathrm{~S}$ culture has resulted in life values such as caring for others, hospitality, tolerance, manners, tolerance, respect and respect for the elder, living more ethically, and having an attitude to preserve culture.
Fifth, in the implementation of character education through the $5 \mathrm{~S}$ culture is needed the role of various parties, both from parents, teachers, and schools, This is important because it will be able to realize the formation of student character more effectively.

The six processes of implementing character education through the $5 \mathrm{~S}$ culture are based on the current condition of concern with the decline of the morale of the next generation, both because of the internal factors of the absence of moral education in the family and the absence of children's willingness to receive good moral teaching, Misguided, and external factors due to the negative effects of globalization, and bad association, so that the government designs character education, and one of its implementation in SMPN 2 Ngawi through the 5S culture, which produces commendable character, is expected to achieve the vision and mission of the school. 


\section{REFERENCES}

Agboola,Alex, Tsai, Kaun Chen. 2012. Bring Character Education into Classroom. V 1.N 2. P.163-170.ISSN-2165-8714

Aroma, Iga Serpianing \& Dewi Retno Suminar. 2012. Hubungan Antara Tingkat Kontrol Diri dengan Kecenderungan Perilaku Kenakalan Remaja. Journal Psikologi Pendidikan dan Perkembangan. Vol. 1 No 02.

Berkowitz, Marvin W\& Marry Anne Hoppe. 2009. Character Education and Gifted Children. Journal High Ability Studies, Vol.20, Isuue 3, p 131-142.

Character Education Partnership (CEP). 2010. Eleven Principles of Effective Character Education: A Frame Work for School Sucsees. Washington DC.

Cooley. 2008. Legislating Character: Moral Education in North Carolina's Public Schools Educational Studies. 43(3) 1882015 doi:101080/000131940802117563.

Creswel, John W. 2009. Research Design: Qualitative, Quantitative, and Mixed Methods Approaches. Los Angeles: University of Nebraska-Lincoln.

Ferryka, Putri Zudhah. 2016. Program 5S (senyum, sapa, Salam, Sopan, santun) dalam Membangun karakter Siswa sekolah dasar Untuk Menyongsong Generasi Emas. Jurnal Pendidikan Guru sekolah dasar S1. Vol1.No 01.

Gunarso, SD. 2010. Psikologi Perkembangan Anak \& Remaja. Jakarta: PT.Gunung Mulia.

Gunawan, Heri. 2012. Pendidikan Karakter Konsep dan Implementasi. Bandung: Aslfabeta.

Homiak, Marcia. 2007. Moral Character in Stanford Encyclopedia of Philosophy Standford.The Maetaphsysics Research Lab, Center for Study of language and Information.

Kemendiknas. 2011. Surat Edaran Pendidikan Karakter. (Online), (http://swaraguru. files.wordpress.com/2011/07/surat edaran pendidikan- karakter.pdf), diakses Sabtu,tanggal 5 Agustus 2017.
Koesoema, Doni. 2010. Pendidikan Karakter Strategi Mendidik anak di Zaman Global. Jakarta: Grasindo.

Lickona, Thomas. 2012. Educating for Character, mendidik untuk membentuk karakter, bagaimana sekolah dapat memberikan pendidikan tentang sikap hormat dan tanggung jawab (Terjemahan Juna Abdu Wamaungo). New York: Bantam Books.

Maisyaroh.. 2016. Membangun Budaya dan Iklim Sekolah di Era Global. (Online), (http//op.fip. um.ac.id/wp-content/uploads/2016/03/45Maisyaroh.pdf.), diakses tanggal 7 Agustus 2017.

Pratiwi, Ika Ari.2012. Pembiasaan Budaya 5S untuk Menumbuhkan Nilai Karakter dan Budi Pekerti. Proceding Seminar nasional 15 Naret 2017, Universitas Muria Kudus.

Sharma, Sagar. 2016. Impact of Globalization on Mental Health in Low and Middle-1 Home Countries SAGE Journal Psychological and Developing Scienties. Vol 28.No.7.

Sudrajat,Ajat. 2011. Membangun Budaya Sekolah Berbasis Karakter Terpuji: Pendidikan Karakter dalam Perspektif Teori dan Praktik. Yogyakarta: UNY Press,

Sudrajat,Akhmad. 2010. Pengembangan Budaya Sekolah. (Online), (http://akhmadsudrajat wordpress. com/2010/03/04/), diakses 6 agustus 2017.

Sugiyono. 2010. Memahami Penelitian Kualitatif. Bandung: Alfabeta.

Ujiningsih. 2010. Pembudayaan Sikap Sopan Santun di Rumah dan di Sekolah Sebagai Upaya untuk Meningkatkan Karakter Siswa. (Online), (http://www.pustaka.ut.ac. id/dev25/pdfprosiding2/fkip201034.pdf), diakses Sabtu tanggal 5 Agustus 2017.

Ulfatin, N. 2015. Metode Penelitian Kualitatif di Bidang Pendidikan: Teori dan aplikasinya. Malang: Media Nusa Kreatif. 